Sains Malaysiana 47(8)(2018): 1819-1826

http://dx.doi.org/10.17576/jsm-2018-4708-21

\title{
Comparison of Fatty Acid Profiles between Successful and Usual Aging Elderly
}

(Perbandingan Profil Asid Lemak antara Orang Tua Penuaan Berjaya dan Biasa)

\author{
NABilah Rosney, HaSnah Haron*, Maihiza SalleH \& SuZana ShaHaR
}

\begin{abstract}
Increased the consumption of polyunsaturated (PUFA) and omega-3 fatty acid may be one of the strategies to prevent morbidity and mortality among elderly. This study aimed to identify the plasma fatty acid profile and intake among older adults who aged successfully (SA) as compared to the usual agers (UA). This cross-sectional comparative study

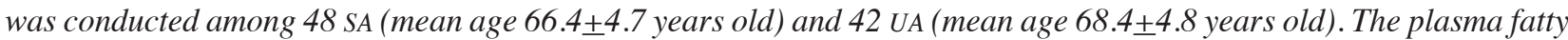
acid profile was determined using gas chromatography. Fatty acid intake was measured by using the validated Fatty Acid Omega-3 intake food frequency questionnaire. The percentage of saturated fatty acids (SFA) in blood plasma of

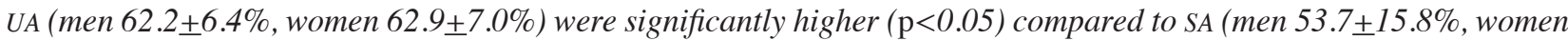
$57.1 \pm 9.5 \%)$. On the other hand, the percentage of monounsaturated (MUFA), polyunsaturated (PUFA) omega-3 and

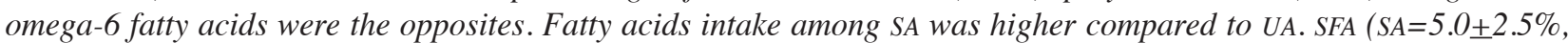
$U A=4.6 \pm 2.9 \%)$ and total omega-3 $(S A=0.5 \pm 0.4 \%, U A=0.4 \pm 0.3 \%)$ intakes met the recommended nutrient intake (RNI). However, mean intakes of MUFA $(S A=5.3 \pm 2.4 \%, U A=4.7+2.7 \%)$ and linoleic acid (LA) $(S A=0.5 \pm 0.7 \%, U A=0.3 \pm 0.5 \%)$ were below than the RNI. Percentages of subjects who did not meet the RNI for omega-3 and MUFA were $44.2 \%$ and $97.7 \%$ for SA and $47.4 \%$ and $95 \%$ for UA, respectively. SA had a higher level of plasma PUFA and MUFA, but lower in SFA when compared to UA. MUFA and LA were more likely to be inadequate in the diet of older adults, particularly the UA.
\end{abstract}

Keywords: Elderly; fatty acid; omega-3; successful aging; usual aging

\section{ABSTRAK}

Meningkatkan pengambilan asid lemak politaktepu dan asid lemak omega-3 berkemungkinan merupakan salah satu strategi untuk mencegah morbiditi dan mortaliti dalam kalangan warga emas. Kajian ini bertujuan untuk mengenal pasti profil asid lemak plasma dan pengambilan asid lemak dalam kalangan warga emas penuaan berjaya (SA) berbanding penuaan biasa (UA). Kajian perbandingan hirisan lintang ini dijalankan ke atas 48 orang warga emas

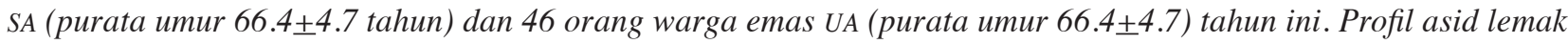
ditentukan menggunakan kromatografi gas. Pengambilan asid lemak pula diukur menggunakan borang soal selidik Kekerapan Pengambilan Makanan Asid Lemak Omega-3 yang telah disahkan. Peratusan asid lemak tepu (SFA) dalam plasma darah warga emas UA (lelaki $62.2 \pm 6.4 \%$, wanita $62.9 \pm 7.0 \%)$ adalah lebih tinggi secara signifikan (p $<0.05)$

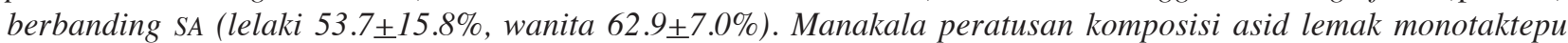
(MUFA), politaktepu (PUFA), omega-3 dan omega-6 adalah sebaliknya. Pengambilan asid lemak adalah lebih tinggi dalam kalangan SA berbanding UA. Pengambilan SFA ( $S A=5.0 \pm 2.5 \%, U A=4.6 \pm 2.9 \%)$ dan omega-3 total ( $S A=0.5 \pm 0.4 \%$, $U A=0.4 \pm 0.3 \%)$ menepati Saranan Pengambilan Nutrien (RNI). Walau bagaimanapun, purata pengambilan MUFA $(S A=5.3 \pm 2.4 \%, U A=4.7 \pm 2.7 \%)$ dan asid linoleik $(L A)(S A=0.5 \pm 0.7 \%, U A=0.3 \pm 0.5 \%)$ pula adalah lebih rendah berbanding RNI. Peratusan subjek yang tidak memenuhi RNI bagi omega-3 dan MUFA pula adalah sebanyak $44.2 \%$ dan $97.7 \%$ bagi SA manakala $47.4 \%$ dan $95 \%$ bagi UA. Kesimpulannya warga emas SA mempunyai tahap PUFA dan MUFA plasma yang tinggi, tetapi rendah tahap SFA berbanding warga emas UA. Pengambilan MUFA dan LA adalah tidak mencukupi dalam diet warga emas, khususnya UA.

Kata kunci: Asid lemak; penuaan Berjaya; penuaan biasa; omega-3; warga emas

\section{INTRODUCTION}

Malaysia is one of the countries where its population is aging and is expected to be the aging nation in 2030 when $15 \%$ of the population is classified as older adults (Samad \& Mansor 2013). According to the Department of Statistics Malaysia (2016), 6\% of 31.7 million Malaysian citizens are comprised of older adults aged 65 years and above. Aging is a complex process (Lacruz et al. 2010).
As we grow older, lots of physiological changes happened and the risk of having disease also increases (WHO 2015). However, if ones can aged successfully, the implications was not only toward the individual, it also give positive effects to the community (Fielding et al. 2011; Gavrilova \& Gavrilov 2010).

The definition and determinants of successful aging is still controversial (Tyrovolas et al. 2014). Rowe and 
Kahn's successful aging concept is one of the popular successful aging model (Cosco et al. 2013). It focuses on high cognitive physical function, low risk of disease and active engagement with the community (Rowe \& Kahn 1997 , 1987). It is widely accepted that dietary patterns are associated with healthy aging (Sofi et al. 2013). However, there is lack of evidence on the role of dietary habits in successful aging (Tyrovolas et al. 2014). One of the dietary patterns that has been extensively studied and associated with longevity is the Mediterranean diet. Higher adherence to this traditional diet is associated with lower overall mortality, reduced risk of cardiovascular diseases and neoplastic diseases (Sofi et al. 2013).

Omega-3 fatty acid is known as a nutrient that has potential to prevent pathological condition that relate to aging process. This fatty acid protects and maintains a better health condition (Ubeda et al. 2012). The intake of foods containing omega-3 among the elderly can help them to improve the quality of life and reduce problems such as depression. It may also help to treat the psychological disease (Freeman 2006). However, little is known about the fatty acids profile and intake among Malaysian older adults and whether these profiles were better among the successful agers. Thus, this study aimed to determine the plasma fatty acid profile and also its intake among successful agers, as compared to the usual agers. Furthermore, correlations between the plasma fatty acid profile and its intake were also determined.

\section{MATERIALS AND METHODS}

\section{STUDY DESIGN AND RESPONDENTS}

This cross-sectional study was conducted among older adults recruited using multistage random sampling from three states of Peninsular Malaysia, i.e. Kelantan, Perak and Selangor. These subjects were part of the Longitudinal Research Grant Scheme Towards Useful Aging (LRGS TUA) that commenced in July 2013. Written consent was obtained from each subject and the study was approved by the Universiti Kebangsaan Malaysia Medical Committee's (UKMMC) Ethical Committee (1.5.3.5/244/NN-060-2013). Eligible subjects were randomly selected and invited to participate for a screening at the respective community centers. Inclusion criteria were aged 60 -years and above; had no mental illness; no serious disease and physical disability; able to read and listen well. Those who change their dietary habits one month prior to data collection and take fish oil supplements were excluded. Subjects were interviewed to collect data on socio-demographic and dietary intake.

\section{CLASSIFICATION OF SUCCESSFUL AND USUAL AGING}

Respondents were classified to particular aging groups according to study reported by Shahar et al. (2015). It was based on the categorization of successful aging (SA) by Hamid et al. (2012), i.e. free from major chronic diseases and has better quality of life and at least feel good about their health. Whilst those who were not met the criteria of successful aging, were categorized as usual aging (UA) (Sun et al. 2010, 2009). A subsample of 48 SA was randomly chosen for fatty acids analysis. A total of 42 UA matched for age and gender; was recruited as comparison through a cross sectional comparative study design. Subjects were also asked to fast for at least 12 $\mathrm{h}$ before the blood collection. However, plain water consumption was allowed. Blood samples were collected in the morning and the plasma samples were stored at $-80^{\circ} \mathrm{C}$ until analyzed.

\section{FATTY ACID INTAKE ASSESSMENT AND ANALYSIS}

Fatty acid intake was assessed using a validated omega-3 intake food frequency questionnaire (Lee et al. 2013). The questionnaire contains 43 food items which categorized under 5 food groups which is fish and seafood, vegetable oils, vegetables, meat and egg and dairy products. US Department of Agriculture Nutrient Database (USDA 2007) was used to analyze the mean intake of fatty acids while the portion size of each food item was based on Malaysian Food Composition Table (Tee et al. 1997). Mean intake of fatty acids, i.e. saturated fatty acids (SFA), monounsaturated fatty acids (MUFA), polyunsaturated fatty acids (PUFA), omega-3, linoleic acid (LA), alphalinolenic acid (ALA), eicosapentanoic acid (EPA) and docosahexanoic acid (DHA) were measured based on the energy intake of the elderly.

\section{PLASMA FATTY ACIDS ANALYSIS}

Blood samples were collected in the morning after $12 \mathrm{~h}$ fast. Plasma samples were stored at $-80^{\circ} \mathrm{C}$ until analyzed. Determination of plasma fatty acids were carried out involving three main procedures, i.e. the extraction of lipids, the transesterification of methyl ester and gas chromatography analysis. $200 \mu \mathrm{l}$ of blood plasma was used to extract lipids according to Folch et al. (1957) followed by the transesterification of the lipids into fatty acid methyl ester (FAME) described by Lepage and Roy (1984).

Separation of FAME was carried out on PerkinElmer Clarus 680 gas chromatograph equipped with flame ionization detector and cyanosiloxane capillary column merged (100 meter length, $0.25 \mathrm{~mm}$ external diameter and $0.2 \mu \mathrm{m}$ internal diameter of SP-2560, Supelco) was used to analyse fatty acids. The initial column temperature was $50^{\circ} \mathrm{C}$, being afterwards increased to $200^{\circ} \mathrm{C}$, at a rate of $3^{\circ} \mathrm{C} / \mathrm{min}$, in which was maintained for $5 \mathrm{~min}$. The temperature of the oven was raised to $220^{\circ} \mathrm{C}$, at a rate of $3^{\circ} \mathrm{C} / \mathrm{min}$, maintained for $17 \mathrm{~min}$. The peaks were identified by comparison of the times retention with the standard solution containing 37 FAME components, Supelco 37 Component FAME Mix (47885-U) in methylene chloride. The flow rates of the gases used were as following: $2 \mathrm{~mL} /$ min for hydrogen gas, $450 \mathrm{~mL} / \mathrm{min}$ for purified air. One cycle of the analysis lasts about 78.67 min per sample. 
The amount of plasma fatty acids, ranging from $\mathrm{C} 4: 0$ to $\mathrm{C} 22: 6 \mathrm{n}-3$, is expressed as percentage of total fatty acids. Plasma saturated fatty acids (SFAs), monounsaturated fatty acids (MUFAs), polyunsaturated fatty acids (PUFAs), omega-3 fatty acids and omega- 6 fatty acids were calculated. In this present analysis, we considered the percentage of individual fatty acids: linoleic acid (LA), alpha-linoleic acid (ALA), eicosapentanoic acid (EPA) and docosahexanoic acid (DHA).

\section{STATISTICAL ANALYSIS}

The statistical analyses were conducted using the Statistical Package of Social Science (SPSS) version 23. Descriptive data are presented as mean + standard deviations (SD) or percentage. Normality test was observed based on skewness and kurtosis and Shapiro-wilk test. Not normally distributed data were log-transformed. All data are normally distributed with the exception of ALA, EPA and DHA which were log-transformed. Differences between groups were tested with an independent t-test and two-way ANOVA. The Pearson correlation test was used to determine the association between the plasma fatty acid composition and fatty acid intake. Categorical data were analyzed using the Chi-squared test.

\section{RESULTS}

There were 90 subjects consisted of 48 SA $(66.4 \pm 4.7$ years) and 42 UA $(68.4 \pm 4.8$ years) who were involved in this study. As shown in Table 1, 26 subjects (54.2\%) in SA group were men and 22 of SA subjects were women $(45.8 \%)$. In UA group, the number of women subjects $(n=24)$ were higher compared to men $(n=18)$. This study involved participants from various ethnicities. In SA group, $52.1 \%$ of the subjects were Chinese followed by Malay $(37.5 \%)$, Indian $(8.3 \%)$ and other ethnicity which is Portuguese $(2.1 \%)$. While in UA group, half of the subjects were Malay $(57.1 \%)$ and the rest were Chinese $(28.6 \%)$ and Indian (14.3\%). The Chi square test showed a significant different $(p<0.05)$ between the education level and the aging group. Most of the SA subjects have education at the secondary level $(39.6 \%)$ while half of the UA subjects have education at the primary level (52.4\%). Majority of the subjects were married (77.0\% among SA and $71.4 \%$ among UA); not working due to retirement (83.3\% among SA and $81.0 \%$ among UA); and had a total household income below RM2000 (77.1\% among SA and $88.1 \%$ among UA).

TABLE 1. Socio-demographic profile of subjects by aging group

\begin{tabular}{|c|c|c|c|}
\hline \multirow[b]{2}{*}{ Parameter } & \multicolumn{2}{|c|}{ Aging group } & \multirow{2}{*}{$\begin{array}{l}\text { Total } \\
(n=90)\end{array}$} \\
\hline & $\begin{array}{c}\text { Successful aging } \\
(n=48)\end{array}$ & $\begin{array}{c}\text { Usual aging } \\
(n=42)\end{array}$ & \\
\hline Age $($ Mean \pm SD $)$ & $66.4 \pm 4.7$ & $68.4 \pm 4.8$ & $67.3 \pm 4.8$ \\
\hline $\begin{array}{l}\text { Gender } \\
\qquad \begin{array}{l}\text { Men } \\
\text { Women }\end{array}\end{array}$ & $\begin{array}{l}26(54.2) \\
22(45.8)\end{array}$ & $\begin{array}{l}18(42.9) \\
24(57.1)\end{array}$ & $\begin{array}{l}44(48.9) \\
46(51.1)\end{array}$ \\
\hline $\begin{array}{l}\text { Ethnicity } \\
\text { Malay } \\
\text { Chinese } \\
\text { Indian } \\
\text { Others }\end{array}$ & $\begin{aligned} 18 & (37.5) \\
25 & (52.1) \\
4 & (8.3) \\
1 & (2.1)\end{aligned}$ & $\begin{array}{c}24(57.1) \\
12(28.6) \\
6(14.3) \\
0(0.0)\end{array}$ & $\begin{array}{c}42(46.7) \\
37(41.1) \\
10(11.1) \\
1(1.1)\end{array}$ \\
\hline $\begin{array}{l}\text { Marital Status } \\
\text { Married } \\
\text { Divorced/Widowed } \\
\text { Single }\end{array}$ & $\begin{array}{l}37(77.0) \\
11(23.0)\end{array}$ & $\begin{array}{l}30(71.4) \\
12(28.6)\end{array}$ & $\begin{array}{l}67(74.4) \\
23(25.6)\end{array}$ \\
\hline $\begin{array}{l}\text { Education } \\
\text { No formal education } \\
\text { Primary } \\
\text { Secondary } \\
\text { Tertiary }\end{array}$ & $\begin{array}{c}3(4.2) \\
16(33.0) \\
19(39.6) \\
10(20.8)\end{array}$ & $\begin{array}{c}6(13.6) \\
22(52.4)^{*} \\
12(28.6) \\
2(4.8)\end{array}$ & $\begin{array}{l}9(10.0) \\
38(42.2) \\
31(28.6) \\
12(13.3)\end{array}$ \\
\hline $\begin{array}{l}\text { Working status } \\
\text { Working } \\
\text { Not working/Retired }\end{array}$ & $\begin{array}{c}8(16.7) \\
40(83.3)\end{array}$ & $\begin{array}{c}8(19.0) \\
34(81.0)\end{array}$ & $\begin{array}{l}16(17.8) \\
74(82.2)\end{array}$ \\
\hline $\begin{array}{l}\text { Household income } \\
\text { Less than RM2000 } \\
\text { More than RM2000 }\end{array}$ & $\begin{array}{l}37(77.1) \\
11(22.9)\end{array}$ & $\begin{array}{c}37(88.1) \\
5(11.9)\end{array}$ & $\begin{array}{l}74(82.2) \\
16(17.8)\end{array}$ \\
\hline
\end{tabular}

$* p<0.05$, significant different between the aging group, Chi Square test 
TABLE 2. Comparison of plasma fatty acid profile between aging group and gender

\begin{tabular}{cccc}
\hline Fatty acid $(\%)$ & Gender & $\begin{array}{c}\text { Successful aging } \\
(n=48)\end{array}$ & $\begin{array}{c}\text { Usual aging } \\
(n=42)\end{array}$ \\
\hline SFA & Men & $53.7 \pm 15.8$ & $62.2 \pm 6.4$ \\
& Women & $57.1 \pm 9.5$ & $62.9 \pm 7.0^{*}$ \\
MUFA & Men & $16.2 \pm 9.3$ & $16.3 \pm 4.4$ \\
& Women & $14.9 \pm 6.2$ & $14.2 \pm 4.5$ \\
PUFA & Men & $27.4 \pm 9.3^{*}$ & $22.3 \pm 5.4$ \\
& Women & $24.4 \pm 5.0$ & $21.6 \pm 5.3$ \\
Omega-3 & Men & $3.6 \pm 3.0$ & $2.0 \pm 1.7$ \\
& Women & $2.7 \pm 1.7$ & $2.8 \pm 1.9$ \\
Omega-6 & Men & $24.1 \pm 8.5^{*}$ & $19.4 \pm 4.7$ \\
& Women & $21.6 \pm 5.4$ & $18.6 \pm 5.7$ \\
LA $^{*}$ & Men & $18.5+5.8^{*}$ & $14.4+3.2$ \\
& Women & $16.3+3.8$ & $13.7+4.4$ \\
& Men & $0.2+0.3$ & $0.5+1.2$ \\
& Women & $0.2+0.1$ & $0.6+1.7$ \\
EPA $^{\mathrm{a}}$ & Men & $0.5+1.2$ & $0.1+0.1$ \\
& Women & $0.4+0.5$ & $0.3+0.3$ \\
DHA $^{\mathrm{a}}$ & Men & $1.6+1.3$ & $1.1+0.7$ \\
& Women & $2.0+1.4^{*}$ & $1.0+0.8$ \\
\hline
\end{tabular}

${ }^{*} p<0.05$, significant different between aging group within the same gender, Two-way ANOVA

${ }^{a}$ Variables were log-transformed before analysis because data were not normally distributed

SFA $=$ Saturated fatty acid, MUFA $=$ Monounsaturated fatty acid, PUFA $=$ Polyunsaturated fatty acid, LA $=$ Linoleic acid, ALA $=$ alpha-Linolenic acid, EPA $=$ Eicosapentanoic acid, DHA $=$ Docosahexanoic acid

\section{PLASMA FATTY ACID PROFILE}

A two-way ANOVA was conducted to examined the effect of gender and aging group on the plasma fatty acid composition (Table 2). There was a statistically significant difference in between the aging group with SFA $F(1,86)=9.74, p=0.002$, PUFA $F(1,86)=7.62, p=0.007$, omega-6 $F(1,86)=8.15, p=0.005$ and LA $F(1,86)=12.16$, $p=0.001$. Besides, there was a statistically significant interaction $F(1,86)=9.03, p=0.003$, between the effects of aging group and gender on the plasma fatty acid composition.

\section{FATTY ACID INTAKE}

All types of fatty acids intake were higher among the SA group. SFA $(5.0 \pm 2.5 \%$ for SA and $4.6 \pm 2.9$ for UA) and omega-3 $(0.5 \pm 0.4 \%$ for SA and $0.4 \pm 0.3 \%)$ intake met the recommendation of the recommended nutrient intake (RNI) for Malaysian. MUFA $(5.3 \pm 2.4 \%$ for SA and $4.7 \pm 2.7 \%$ for $\mathrm{UA})$ and LA ( $0.5 \pm 0.7 \%$ for SA and $0.3 \pm 0.5 \%$ for UA) intakes did not achieve the recommendation (Table 3). Percentages of subjects who did not meet the RNI for omega-3 and MUFA were $44.2 \%$ and $97.7 \%$ for SA and $47.4 \%$ and $95 \%$ for UA while $100 \%$ of subjects did not meet the RNI for LA. Only $4.7 \%$ of sA elderly and $5 \%$ of UA elderly did not met the recommendation of SFA. Fish and seafood contributed the highest percentage to the omega- 3 intake $(51.5 \%$ for SA and $58.9 \%$ for SA), followed by vegetables, milk and dairy products, meat and eggs and the least contributor to the percentage of omega- 3 intake was the vegetable oils.
The percentage of milk and dairy products to the omega-3 intake were significantly $(p<0.05)$ higher among the SA group (13.8\%) compared to UA group (4.9\%).

\section{CORRELATION BETWEEN FATTY ACID INTAKE AND FATTY ACID COMPOSITION IN PLASMA}

LA intake showed a positive significant $(p<0.05)$ relationship with the composition of PUFA $(r=0.246)$, omega-6 $(r=0.241)$ and LA $(r=0.262)$ in plasma. Besides, DHA intake also showed a moderate positive significant $(p<0.01)$ relationship with the PUFA $(r=0.325)$, omega- 6 $(r=0.367)$ and LA $(r=0.390)$ in plasma (Table 4$)$.

\section{DISCUSSION}

The percentage of plasma fatty acids among elderly in this study were close to the findings of the previous studies which have the same range of age (Nirupa et al. 2014; Rise et al. 2013). The composition of PUFA, omega- 3 and omega-6 in plasma were higher among SA elderly compared to UA. These findings were similar to the Cunnane et al. (2012) who found the higher composition of MUFA and omega-6 among elderly who did not have cognitive deficit problem. In addition, the composition of SFA was higher among women subjects in both groups compared to men. This was in contrast to study by Saadatian-Elahi et al. (2009) who reported that the SFA composition was higher among men subjects compare to women. The different composition of plasma fatty acids among sexes may be due 
TABLE 3. Percentage of fatty acid consumption based on energy intake by aging groups

\begin{tabular}{lccc}
\hline \multirow{2}{*}{ Parameter } & \multicolumn{2}{c}{ Aging group } & RNI \\
\cline { 2 - 3 } & $\begin{array}{c}\text { Successful aging } \\
(n=48)\end{array}$ & $\begin{array}{c}\text { Usual aging } \\
(n=42)\end{array}$ & $\begin{array}{c}(\text { NCCFN } \\
2017)\end{array}$ \\
\hline SFA (\%) & $5.0 \pm 2.5$ & $4.6 \pm 2.9$ & $<10 \%$ \\
MUFA (\%) & $5.3 \pm 2.4$ & $4.7 \pm 2.7$ & $12-15 \%$ \\
PUFA (\%) & $3.0 \pm 1.4$ & $2.9 \pm 1.7$ & - \\
Total omega-3 (\%) & $0.5 \pm 0.4$ & $0.4 \pm 0.3$ & $0.3-1.2 \%$ \\
LA (\%) & $0.5 \pm 0.7$ & $0.3 \pm 0.5$ & $3-7 \%$ \\
ALA (\%) & $1.7 \pm 10.6$ & $0.02 \pm 0.03$ & - \\
EPA (\%) & $0.0005 \pm 0.001$ & $0.0002 \pm 0.0004$ & - \\
DHA (\%) & $0.003 \pm 0.006$ & $0.002 \pm 0.003$ & - \\
\hline
\end{tabular}

to the dietary habits as well as the fatty acid metabolism that differ between men and women. The rate of omega-3 PUFA synthesis was higher in women (Childs et al.2008) and the estrogen hormones will further increase the conversion of ALA to DHA (Kitson et al. 2010).

Though the omega-3 fatty acids intake met the recommendation of $0.3-1.2 \%$ of energy intake, the value was still low, with $44.2 \%$ of SA and $47.4 \%$ of UA did not meet the RNI. Findings of this study were in agreement with earlier study by Lee et al. (2013) among older adults residing low cost housing area in Klang Valley of Malaysia. As shown in Figure 1, almost half of the subjects in both aging groups did not meet the recommendations of RNI for omega-3 intake. Their intake of omega- 3 only achieved $0.5 \%$ (SA) and $0.4 \%$ (UA) of the recommendations. However, the problem of this inadequacy of omega- 3 intake was not just among the elderly, about average Malaysian's intakes of omega- 3 remains low and there are several ways that we can remedy this, namely: consuming more pulses (e.g. beans, dhal), tofu and fishes and use a cooking oil that is a blend of palm olein $+n-3$ rich vegetable oil (e.g. canola, soybean) (NCCFN 2017).

The intake of MUFA was much lower than the RNI and this may due to the fact that oils high in MUFA i.e. olive
$(76 \%)$, mustard $(70 \%)$, almond $(69 \%)$, canola $(62 \%)$ and groundnut $(50 \%)$, are not the main cooking oil in Malaysia. Food and Agriculture Organization (FAO) (2011) reported palm oil represents the main cooking oils for most Malaysians, as this country is a primary producer of palm oil. The same goes to LA which mainly comes from vegetables oils such as soybean and canola oils.

Besides that, the intake of SFA was also within the RNI recommendation of $<10 \%$ of energy intake and fewer subjects did not meet the recommendation of SFA. Similar to the findings of Micha et al. (2014) where the intake of SFA was about 9.2-9.5\% for Malaysian adults, however, with this number, Malaysia was still one of the countries with the highest intake of SFA. This study had no problems of under-reporting or over-reporting for both aging groups. Fish and seafood contributed most of the percentage of omega- 3 intake followed by vegetables, milk and dairy products, meat and eggs and also vegetable oils. This finding was different from the Australian population where almost $50 \%$ of their omega-3 intake came from meat sources (Howe et al. 2006).

SFA and MUFA have a negative correlation with consumption. As expected, the SFA and MUFA in plasma did not reflect their consumption in the diet and the results

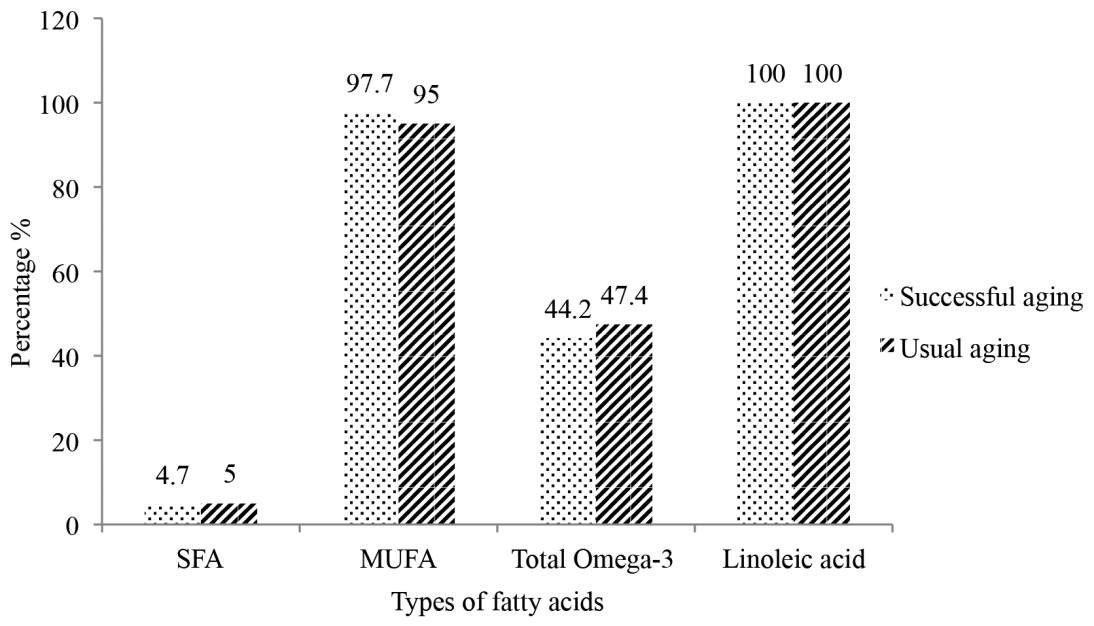

FIGURE 1. Percentage of subjects did not meet the fatty acids recommendation 


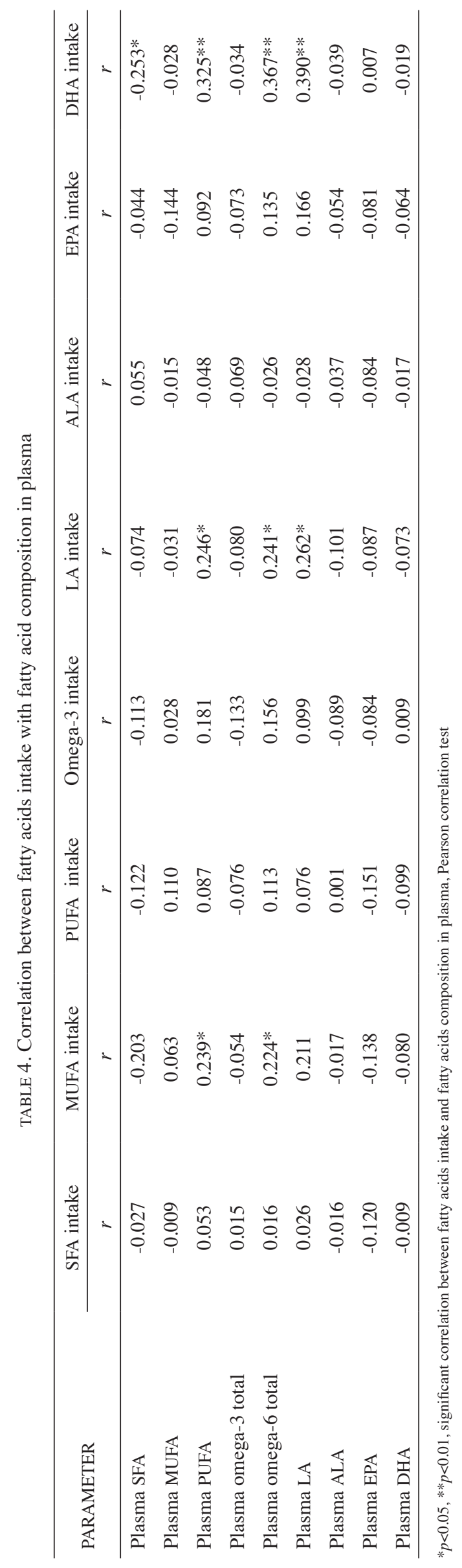


of this study were supported by Sun et al. (2007). SFA and MUFA were not considered as a good biomarker to reflect the consumption of foods because it can be produced by the body through carbohydrates. However, some fatty acids like PUFA, omega-6, omega-3 and odd saturated fatty acids (C15:0 \& C17:0) were good biomarkers (Baylin $\&$ Campos 2006). Essential fatty acids such as LA were expected to show a direct correlation between plasma concentration and the food intake (Saadatian-Elahi et al. 2009). This study found a positive significant correlation between the intake of LA and DHA with the composition of PUFA, total omega-6 and LA in plasma. Similarly, Sun et al. (2007) found a positive correlation $(r=0.26)$ between LA composition in plasma and its intake. However, a perfect correlation between the composition of fatty acids in the tissues and blood with its intake was unrealistic (Sun et al. 2007). This was because there were other factors that affect the composition of fatty acids such as genetics, smoking, physical activity and metabolism (Hodson et al. 2008).

\section{CONCLUSION}

Successful aging was associated with a higher MUFA, PUFA and lower SFA in plasma. SA had a higher consumption of all types of fatty acids. Regardless of aging groups, SFA and omega- 3 but not MUFA and LA met the recommended intake for Malaysian population. Composition of LA in plasma reflected its intake in the diet. There is a need to promote consumption of fish, seafood and nuts as good sources of fatty acids that lead to successful aging.

\section{ACKNOWLEDGEMENTS}

The authors would like to thank the Ministry of Education (Malaysia), for the Longitudinal Research Grant Scheme towards Useful Aging (LRGS TUA), LRGS/BU/2012/UKM$\mathrm{UKM} / \mathrm{K} / 01$ for the financial support of this study. We also would to thank all the enumerators and respondents of the study for their cooperation and patience.

\section{REFERENCES}

Baylin, A. \& Campos, H. 2006. The use of fatty acid biomarkers to reflect fatty acid intake. Current Opinion in Lipidology 17: 22-27.

Childs, C.E., Romeu-Nadal, M., Burdge, G.C. \& Clader, P.C. 2008. Gender differences in the $n-3$ fatty acid content of tissues. Proceedings of the Nutrition Society 67: 19-27.

Cosco, T.D., Prina, A.M., Perales, J., Stephan, B.C.M. \& Brayne, C. 2013. Lay perspectives of successful ageing: A systematic review and meta-ethnography. BMJ Open 3(6): e002710.

Cunnane, S.C., Schneider, J.A., Tangney, C., Tremblay-Mercier, J., Fortier, M., Bennet, D.A. \& Morris, M.C. 2012. Plasma and brain fatty acid profiles in mild cognitive impairment and Alzheimer's disease. Journal of Alzheimer Disease 29(3): 691-697.

FAO. 2011. Food supply - Crops primary equivalent. http:// faostat3.fao.org/download/FB/CC/E. Accessed on 24 February 2018.
Fielding, R.A., Rejeski, W.J., Blair, S., Church, T., Espeland, M.A. \& Gill, T.M. 2011. The lifestyle interventions and independence for elders study: Design and methods. The Journal of Gerontology. Series A, Biological Sciences and Medical Sciences 66: 1226-1237.

Folch, J., Lees, M. \& Stanley, G.H.S. 1957. A simple method for isolation and purification of total lipids from animal tissues. The Journal of Biological Chemistry 226: 497-509.

Gavrilova, N.S. \& Gavrilov, L.A. 2010. Search for mechanisms of exceptional human longevity. Rejuvenation Research 13: 262-264.

Hamid, T.A., Momtaz, Y.A. \& Ibrahim, R. 2012. Predictors and prevalence of successful aging among older Malaysians. Gerontology 58(4): 366-370.

Hodson, L., Skeaff, C.M. \& Fielding, B.A. 2008. Fatty acid composition of adipose tissue and blood in humans and its use as a biomarker of dietary intake. Progress in Lipid Research 47(5): 348-380.

Howe, P.R.C., Meyer, B.J., Record, S. \& Barghurst, K. 2006. Dietary intake of long-chain $n-3$ polyunsaturated fatty acids: Contribution meat sources. Nutrition 22: 47-53.

Kitson, A.P., Stroud, C.K. \& Stark, K.D. 2010. Elevated production of docosahexanoic acid in females: Potential molecular mechanisms. Lipids 45(3): 209-224.

Lacruz, M.E., Emeny, R.T., Bickel, H., Cramer, B., Kurz, A., Bidlingmaier, M., Huber, D., Klug. G., Peters, A. \& Ludwig, K.H. 2010. Mental health in the aged: Prevalence covariates and related neuroendocrine cardiovascular and inflammatory factors of successful aging. BMC Medical Research Methodology 10: 36.

Lee, L.K., Suzana, S., Yusoff, N.A.M. \& Chin, A.V. 2013. Validation of a food frequency questionnaire in assessing the omega-3 polyunsaturated fatty acids intake for Malays and Chinese elderly in Malaysia. Sains Malaysiana 42(11): 1625-1632.

Lepage, G. \& Roy, C.C. 1984. Improved recovery of fatty acid through direct transesterification without prior extraction or purification. Journal of Lipid Research 25: 1391-1396.

Micha, R., Khatibzadeh, S., Shi, P., Fahimi, S., Lim, S., Andrews, K.G., Engell, R.E., Powles, J., Ezzati, M. \& Mozaffirin, D. 2014. Global, regional and national consumption of dietary fats and oils in 1990 and 2010: A systematic analysis including 266 country-specific nutrition surveys. BMJ 348 : g2272.

Nirupa, R.M., Esther, M.O., Linda, V.H., Marian, L.N., Richard, W. \& Alice, L.H. 2014. Plasma phospholipid fatty acid biomarkers of dietary fat quality and endogenous metabolism predict coronary heart disease: A nested case-control study within the Women's Health Initiative Study. Journal of American Heart Association 3(4): e000764.

National Coordinating Committee on Food and Nutrition. 2017. Recommended nutrient intakes for Malaysia: A report of the technical working group on nutritional guidelines. Putrajaya: Ministry of Health Malaysia.

Rise, P., Eligini, S., Ghezzi, S., Colli, S. \& Galli, C. 2007. Fatty acid composition of plasma, blood cells and whole blood: Relevance for the assessment of the fatty acid status in humans. Prostaglandins, Leukotrienes and Essential Fatty Acids 76: 363-369.

Rowe, J.W. \& Kahn, R.L. 1997. Successful aging. Gerontologist 37: 433-440.

Rowe, J.W. \& Kahn, R.L. 1987. Human aging: Usual and successful. Science 237: 143-149. 
Saadatian-Elahi, M., Nadia, S., Veronique, C., Mazda, J., Joelle, G., Carine, B., Pietro, F., Graham, B., Philippe, A., Petra, H.M., Marga, O. \& Elio, R. 2009. Plasma phospholipid fatty acid profile sand their association with food intakes: Results from a cross-sectional study within the European Prospective Investigation into Cancer and Nutrition. American Journal Clinical of Nutrition 89: 331-346.

Samad, S.A. \& Mansor, N. 2013. Population aging and social protection in Malaysia. Malaysian Journal of Economic Studies 50(2): 139-156.

Shahar, S., Omar, A., Vanoh, D., Hamid, T.A., Mukari, S.Z., Din, N.C., Rajab, N.F., Mohammed, Z., Ibrahim, R., Loo, W.H., Meramat, A., Kamaruddin, M.Z., Bagat, M.F. \& Razali, R. 2015. Approaches in methodology for population-based longitudinal study on neuroprotective model for healthy longevity (TUA) among Malaysian older adults. Aging Clinical Experiment Research 28(6): 1089-1104.

Sofi, F., Macchi, C., Abbate, R. \& Gensini, G.F. 2013. Mediterranean diet and health status: An updated metaanalysis and a proposal for a literature-based adherence score. Public Health Nutrition 17(12): 2769-2782.

Sun, Q., Ma, J., Campos, H., Hankinson, S.E. \& Hu, F.B. 2007. Comparison between plasma and erythrocyte fatty acid content as biomarkers of fatty acid intake in US women. The American Journal of Clinical Nutrition 86: 74-81.

Sun, Q., Townsend, M.K., Okereke, O.I., Franco, O.H., Hu, F.B. \& Grodstein, F. 2010. Physical activity at midlife in relation to successful survival in women at age 70 years or older. Archieves of Internal Medicine 170(2): 194-201.

Sun, Q., Townsend, M.K., Okereke, O.I., Franco, O.H., Hu, F.B. \& Grodstein, F. 2009. Adiposity and weight change in midlife in relation to healthy survival after age 70 in women: Prospective cohort study. BMJ 339: b3796.

Tee, E.S., Ismail, M.N., Nasir, M.A. \& Khatijah, I. 1997. Nutrient Composition of Malaysian Foods. Kuala Lumpur: Asean Food Habits Project.
Tyrovolas, S., Haro, J.M., Mariolis, A., Piscopo, S., Valacchi, G., Tsakountakis, N., Zeimbekis, A., Tyrovola, D., Bountziouka, V. \& Gotsis, E. 2014. Successful aging, dietary habits and health status of elderly individuals: A k-dimensional approach within the multi-national MEDIS study. Experimental Gerontology 60: 57-63.

Ubeda, N., Anchon, M. \& Varela-Moreiras, G. 2012. Omega 3 fatty acids in the elderly. British Journal of Nutrition 107: 137-151.

WHO. 2015. World Report on Ageing and Health. Geneva: World Health Organization.

Nabilah Rosney, Hasnah Haron* \& Maihiza Salleh Nutritional Sciences Programme, School of Healthcare Sciences Faculty of Health Sciences

Universiti Kebangsaan Malaysia

Jalan Raja Muda Abdul Aziz, 50300 Kuala Lumpur, Federal Territory

Malaysia

Suzana Shahar

Dietetic Programme, Centre of Healthcare Sciences

Faculty of Health Sciences

Universiti Kebangsaan Malaysia

Jalan Raja Muda Abdul Aziz

50300 Kuala Lumpur, Federal Territory

Malaysia

*Corresponding author; email: hasnaharon@ukm.edu.my

Received: 21 September 2017

Accepted: 19 April 2018 